\title{
PERAN KANTOR URUSAN AGAMA DALAM MENGURANGI TINGGINYA ANGKA PERCERAIAN DI KABUPATEN BOJONEGORO (Study pada Kantor Urusan Agama di Kabupaten Bojonegoro)
}

\author{
Mochammad Mansur'), Ichwal Subagjo ${ }^{2)}$ \\ ${ }^{1}$ Fakultas Hukum, Universitas Bojonegoro \\ Email: mochamadmansuresha@gmail.com \\ ${ }^{2}$ Fakultas Hukum, Universitas Bojonegoro \\ Email: ichwalsubagjo123@gmail.com
}

\begin{abstract}
Abstrak
Setiap pasangan yang melaksanakan perkawinan selalu menginginkan terciptanya keluarga harmonis dan kebahagiaan dapat diwujudkan dengan komitmen dari setiap pasangan agar tidak berakhir dengan perceraian, dan itu merupakan sebagian tanggung jawab dari Kantor Urusan Agama (KUA) yang memiliki tugas membina keberlanjutan perkawinan. Penelitian ini menggunakan metode penelitian empiris yang memiliki objek studi tentang perilaku masyarakat, dengan metode pengumpulan bahan wawancara. Hasil penelitian ini menguraikan bahwa peranan Kantor Urusan Agama dalam mengurangi angka perceraian di Kabupaten Bojonegoro adalah dengan menerapkan beberapa kebijakan yang sifatnya preventif dan berkelanjutan di antaranya adalah Bimbingan Perkawinan, Penasehatan Pra-Nikah Non Calon Pengantin, Penasehatan Pra-Nikah, Penyuluhan Keluarga Sakinah.
\end{abstract}

Kata Kunci: Perkawinan, Perceraian, Peran Kantor Urusan Agama

\begin{abstract}
Every couple has been married always wants the creation of a harmonious family and happiness can be realized with commitment from each partner so that doesn't in divorce and this is part of the responsibility of the Religious Affairs Office (KUA) has the task of fostering marital sustainability. This study using an empirical research method that has the object of study of people's behavior, with the method of interview material collection. The results of this study describe that the role of Office Religious Affairs in reducing divorce rates in Bojonegoro Regency by implementation some preventive and sustainable include Marriage Guidance, PreMarriage Counseling for Non-Prospective Brides, Pre-Marriage Counseling, Counseling of Sakinah Families.
\end{abstract}

Keywords: Marriage, Divorce, Role of religious Affairs office.

\section{PENDAHULUAN}

Perkawinan tidak hanya menyangkut masalah pribadi dari para pihak yang menjalankan perkawinan, melainkan juga menyangkut masalah keluarga, kerabat bahkan masyarakat. Pada dasarnya tujuan perkawinan adalah membentuk keluarga yang bahagia dan kekal, untuk itu suami isteri perlu saling membantu dan melengkapi, agar masing-masing dapat mengembangkan kepribadiannya serta membantu dan mencapai kesejahteraan baik secara spiritual maupun materiil (Penjelasan Undang-Undang Nomor 1 Tahun 1974 tentang Perkawinan). Namun mewujudkan sebuah rumah tangga/keluarga yang harmonis bukan 
persoalan yang mudah, berbagai perselisihan dan masalah yang timbul antara suami dan istri dapat memicu pertengkaran hingga berujung proses perceraian dan anak-anak merupakan pihak yang akan merasakan akibatnya. Pada hakikatnya putusnya perkawinan adalah istilah hukum yang digunakan dalam UU Perkawinan untuk menjelaskan perceraian atau berakhirnya hubungan perkawinan antara seorang laki-laki dengan perempuan yang telah hidup sebagai suami istri (Amir Syarifuddin, 2009). Berdasarkan ketantuan Pasal 38 UU Perkawinan, bahwa Perkawinan dapat putus karena:

a. Kematian;

b. Perceraian dan

c. Atas keputusan Pengadilan.

Sedangkan ketentuan Pasal 39 ayat (1) UU Perkawinan menerangkan bahwa Perceraian hanya dapat dilakukan di depan Sidang Pengadilan setelah Pengadilan yang bersangkutan berusaha dan tidak berhasil mendamaikan kedua belah pihak. Sebuah ironi melihat angka perceraian yang cukup tinggi di Kabupaten Bojonegoro dengan keadaan geografis yang tergolong masyarakat agraris. Untuk melakukan perceraian harus ada cukup alasan, sebagaimana yang tercantum dalam pasal 39 UU Perkawinan Jo. pasal 19 Peraturan Pemerintah Nomor 9 tahun 1975 tentang Perkawinan. Pada prinsipnya perceraian merupakan lepasnya ikatan perkawinan antara seorang pria dengan seorang wanita sebagai suami-isteri, yang dilakukan di depan sidang Pengadilan, yaitu Pengadilan Negeri untuk non muslim dan Pengadilan Agama untuk yang beragama Islam. Dalam Pasal 19 Peraturan Pemerintah Nomor 9 tahun 1975 tentang Perkawinan menyebutkan alasan perceraian di antaranya adalah sebagai berikut:

1. Salah satu pihak berbuat zina atau menjadi pemabuk, pemadat dan lain sebagainya yang sukar disembuhkan;

2. Salah satu pihak meninggalkan pihak lain selama 2 (dua) tahun berturut-turut tanpa izin pihak lain dan tanpa alasan yang sah atau karena hal lain di luar kemampuannya;

3. Salah satu pihak mendapat hukuman penjara 5 (lima) tahun atau hukuman yang lebih berat setelah perkawinan berlangsung;

4. Salah satu pihak melakukan kekejaman atau penganiayaan yang membahayakan pihak lain;

5. Salah satu pihak mendapat cacat badan atau penyakit dengan akibat tidak dapat menjalankan kewajibannya sebagai suami/isteri;

6. Antara suami dan isteri terus menerus terjadi perselisihan dan pertengkaran serta tidak ada harapan akan hidup rukun lagi dalam rumah tangga.

Dalam mengurangi angka perceraian di Kabupaten Bojonegoro tentu membutuhkan peran serta dari para pihak terutama dari Kantor Urusan Agama yang memiliki tugas pencatatan perkawinan sekaligus pelestarian dan pembinaan perkawinan. Sejak Januari 2018 Kantor Urusan Agama Kecamatan Gayam telah terbentuk, sehingga Desa yang semula terintegrasi di KUA Kecamatan Kalitidu maupun Kecamatan Ngasem masuk di wilayah KUA Kec. Gayam dan jumlah total hingga saat ini tercatat berjumlah 28 Kantor Urusan Agama yang ada di Kabupaten Bojonegoro. Berikut ini merupakan tabel terkait dengan Kantor Urusan Agama (KUA) yang ada di Kabupaten Bojonegoro, di antaranya adalah sebagai berikut:

\begin{tabular}{|c|c|c|}
\hline NO. & NAMA KUA & ALAMAT \\
\hline 1. & $\begin{array}{c}\text { KUA Kec. } \\
\text { Baureno }\end{array}$ & $\begin{array}{c}\text { Jl. Raya Kepohbaru } \\
\text { No. 529 Mongkrong }\end{array}$ \\
\hline 2. & $\begin{array}{c}\text { KUA Kec. } \\
\text { Kepohbaru }\end{array}$ & $\begin{array}{c}\text { Dusun Baru, Desa } \\
\text { Sidomukti, } \\
\text { Kepohbaru }\end{array}$ \\
\hline 3. & KUA Kec. & $\begin{array}{c}\text { Jl. Gajah Mada } \\
\text { Kedungadem }\end{array}$ \\
\hline 4. & $\begin{array}{c}\text { KUA Kec. } \\
\text { Kanor }\end{array}$ & $\begin{array}{c}\text { Jl. Raya No. 81 } \\
\text { Dusun Prijek Desa } \\
\text { Tambahrejo }\end{array}$ \\
\hline
\end{tabular}




\begin{tabular}{|c|c|c|}
\hline 5 & $\begin{array}{l}\text { KUA Kec. } \\
\text { Sumberrejo }\end{array}$ & $\begin{array}{c}\text { Dusun Kauman Desa } \\
\text { Sumberrejo }\end{array}$ \\
\hline 6 & $\begin{array}{l}\text { KUA Kec. } \\
\text { Balen }\end{array}$ & $\begin{array}{c}\text { Jl. Masjid No. } 338 \\
\text { Desa Balenrejo } \\
\text { Balen }\end{array}$ \\
\hline 7 & $\begin{array}{l}\text { KUA Kec. } \\
\text { Sukosewu }\end{array}$ & $\begin{array}{l}\text { J1. Raya Sukosewu } \\
\text { No. } 147 \text { Desa } \\
\text { Sukosewu }\end{array}$ \\
\hline 8 & $\begin{array}{l}\text { KUA Kec. } \\
\text { Sugihwaras }\end{array}$ & $\begin{array}{l}\text { Jl. Masjid No. } 435 \\
\text { Desa Sugihwaras }\end{array}$ \\
\hline 9 & $\begin{array}{l}\text { KUA Kec. } \\
\text { Kapas }\end{array}$ & $\begin{array}{c}\text { Jl. Masjid No. } 66 \\
\text { Gg. Kauman Desa } \\
\text { Kapas }\end{array}$ \\
\hline 10 & $\begin{array}{l}\text { KUA Kec. } \\
\text { Bojonegoro }\end{array}$ & $\begin{array}{c}\text { J1. KH. Mansyur No. } \\
52 \text { Kel. } \\
\text { Mojokampung }\end{array}$ \\
\hline 11 & $\begin{array}{l}\text { KUA Kec. } \\
\text { Trucuk }\end{array}$ & $\begin{array}{c}\text { Desa Guyangan Kec. } \\
\text { Trucuk Bojonegoro }\end{array}$ \\
\hline 12 & $\begin{array}{l}\text { KUA Kec. } \\
\text { Dander }\end{array}$ & $\begin{array}{l}\text { Jl. Raya No. } 142 \\
\text { Desa Dander }\end{array}$ \\
\hline 13 & $\begin{array}{l}\text { KUA Kec. } \\
\text { Temayang }\end{array}$ & $\begin{array}{l}\text { Jl. Basuki Rahmad } \\
\text { Desa Temayang } \\
\text { Bojonegoro }\end{array}$ \\
\hline 14 & $\begin{array}{l}\text { KUA Kec. } \\
\text { Bubulan }\end{array}$ & $\begin{array}{l}\text { Jl. Masjid No. } 250 \\
\text { Bubulan Bojonegoro }\end{array}$ \\
\hline 15 & $\begin{array}{l}\text { KUA Kec. } \\
\text { Gondang }\end{array}$ & $\begin{array}{c}\text { Dusun Ngepeh Desa } \\
\text { Senganten Kec. } \\
\text { Gondang }\end{array}$ \\
\hline 16 & $\begin{array}{l}\text { KUA Kec. } \\
\text { Sekar }\end{array}$ & $\begin{array}{l}\text { Jl. Cempaka, } \\
\text { Lokendat, Desa } \\
\text { Miyono Sekar }\end{array}$ \\
\hline
\end{tabular}

\begin{tabular}{|c|c|c|}
\hline 17 & $\begin{array}{l}\text { KUA Kec. } \\
\text { Kalitidu }\end{array}$ & $\begin{array}{c}\text { J1. Raya Kalitidu No. } \\
202 \text { Krajan Kec. } \\
\text { Kalitidu }\end{array}$ \\
\hline 18 & $\begin{array}{l}\text { KUA Kec. } \\
\text { Ngasem }\end{array}$ & $\begin{array}{c}\text { Dusun Papringan } \\
\text { Desa Dukohkidul } \\
\text { Kec.Ngasem }\end{array}$ \\
\hline 19 & $\begin{array}{l}\text { KUA Kec. } \\
\text { Ngambon }\end{array}$ & $\begin{array}{l}\text { J1. Ps. Ngambon } \\
\text { Kec. Ngambon } \\
\text { Bojonegoro }\end{array}$ \\
\hline 20 & $\begin{array}{l}\text { KUA Kec. } \\
\text { Malo }\end{array}$ & $\begin{array}{c}\text { Jl. Sukandar No. } 295 \\
\text { Desa Ketileng Kec. } \\
\text { Malo }\end{array}$ \\
\hline 21 & $\begin{array}{l}\text { KUA Kec. } \\
\text { Purwosari }\end{array}$ & $\begin{array}{c}\text { Jl. Tambangan I } \\
\text { Kopjan Purwosari }\end{array}$ \\
\hline 22 & $\begin{array}{l}\text { KUA Kec. } \\
\text { Gayam }\end{array}$ & $\begin{array}{l}\text { Desa Ringintunggal } \\
\text { Gayam Bojonegoro }\end{array}$ \\
\hline 23 & $\begin{array}{l}\text { KUA Kec. } \\
\text { Tambakrejo }\end{array}$ & $\begin{array}{c}\text { Jl. Ngraho No. } 85 \\
\text { Brabo Sukorejo } \\
\text { Tambakrejo }\end{array}$ \\
\hline 24 & $\begin{array}{l}\text { KUA Kec. } \\
\text { Padangan }\end{array}$ & $\begin{array}{l}\text { Jl. Bojonegoro- } \\
\text { Ngawi No. } 129 \\
\text { Padangan }\end{array}$ \\
\hline 25 & $\begin{array}{l}\text { KUA Kec. } \\
\text { Ngraho }\end{array}$ & $\begin{array}{l}\text { J1. Arif Rahman } \\
\text { Hakim No. } 26 \text { Desa } \\
\text { Ngraho }\end{array}$ \\
\hline 26 & $\begin{array}{c}\text { KUA Kec. } \\
\text { Margomulyo }\end{array}$ & $\begin{array}{l}\text { Desa Margomulyo } \\
\text { Kec. Margomulyo }\end{array}$ \\
\hline 27 & $\begin{array}{c}\text { KUA Kec. } \\
\text { Kasiman }\end{array}$ & $\begin{array}{c}\text { Jl. Wonosari No. } 7 \\
\text { Sendang Kijing } \\
\text { Sambeng }\end{array}$ \\
\hline 28 & $\begin{array}{l}\text { KUA Kec. } \\
\text { Kedewan }\end{array}$ & $\begin{array}{c}\text { Jl. Raya Kedewan } \\
\text { Kedewan } \\
\text { Bojonegoro }\end{array}$ \\
\hline
\end{tabular}




\section{Rumusan Masalah}

Bagaimanakah peran Kantor Urusan Agama dalam mengurangi tingginya angka perceraian di Kabupaten Bojonegoro?

\section{Tujuan Penelitian}

Untuk mengetahui peran Kantor Urusan Agama dalam mengurangi tingginya angka perceraian di Kabupaten Bojonegoro.

\section{METODE PENELITIAN}

\subsection{Jenis Penelitian}

Jenis metode penelitian yang digunakan dalam penelitian ini adalah metode penelitian empiris, artinya mempunyai objek kajian mengenai perilaku masyarakat. Perilaku masyarakat yang dikaji adalah perilaku yang timbul akibat berinteraksi dengan sistem norma yang ada. Interaksi tersebut muncul sebagai bentuk reaksi masyarakat atas diterapkannya sebuah ketentuan perundangan positif dan bisa pula dilihat dari perilaku masyarakat sebagai bentuk aksi dalam memengaruhi pembentukan sebuah ketentuan hukum positif. (Mukti Fajar, Yulianto Achmad, 2017).

2.2 Fokus Penelitian

Penelitian ini difokuskan untuk mengetahui dan menganalisis peranan Kantor Urusan Agama dalam mengurangi tingginya angka perceraian di Kabupaten Bojonegoro.

\subsection{Lokasi Penelitian}

Lokasi penelitian yang akan digunakan untuk mendapatkan beberapa informasi dan bahan hukum di antaranya adalah sebagai berikut: Kantor Kementerian Agama Kabupaten Bojonegoro dan Kantor Urusan Agama se-Kabupaten Bojonegoro;

2.4 Metode Pendekatan

Metode Pendekatan yang dipergunakan dalam penelitian ini akan menggunakan beberapa pendekatan, yaitu: (Peter Mahmud Marzuki, 2009)

\section{Pendekatan Konsep (Conseptual Approach)}

adalah pendekatan yang beranjak dari pandangan-pandangan dan doktrin-doktrin yang berkembang di dalam ilmu hukum, guna menemukan ide-ide yang melahirkan pengertian, konsep, dan asas hukum yang relevan, sebagai sandaran dalam membangun suatu argumentasi hukum dalam memecahkan isu hukum yang dihadapi.

2. Pendekatan Historis (Historical Approach)

adalah pendekatan yang dilakukan dengan menelaah latar belakang apa yang dipelajari dan perkembangan pengaturan mengenai isu hukum yang dihadapi. Telaah demikian diperlukan oleh peneliti untuk mengungkap filosofi dan pola pikir yang melahirkan sesuatu yang sedang dipelajari.

2.5 Sumber Bahan Hukum dan Pengolahan Bahan Hukum

1. Wawancara

Wawancara merupakan cara yang digunakan untuk memperoleh keterangan secara lisan guna mencapai tujuan tertentu dan tujuan ini dapat bermacam-macam, antara lain untuk diagnosa dan treatment seperti yang biasa dilakukan oleh psikoanalis dan dokter atau untuk keperluan mendapat berita seperti yang dilakukan oleh wartawan dan untuk melakukan penelitian dan lain-lain (Burhan Ashshofa, 2010).

2. Bahan hukum mengikat berupa undangundang

Undang-Undang Nomor 1 Tahun 1974 tentang Perkawinan, Peraturan Pemerintah Nomor 9 tahun 1975 tentang Perkawinan dan Kompilasi Hukum Islam.

2.6 Analisis Bahan Hukum

Analisis dalam penelitian ini dilakukan secara deskriptif kualitatif, yang artinya sama dengan penelitian etnografi yang bertujuan untuk menemukan pola-pola kebudayaan yang membuat hidup menjadi berarti bagi orang atau masyarakat, teknik penelitian yang digunakan adalah wawancara mendalam (depth interview), pengamatan terlibat (participant observation) dan dokumen pribadi seperti buku harian, surat-surat, otobiografi, transkrip dan wawancara tidak berstruktur (Burhan Ashshofa, 2010). 


\section{HASIL DAN PEMBAHASAN}

Berdasarkan data yang telah didapatkan oleh peneliti pada Seksi BIMAS Islam Kantor Kementerian Agama Kab. Bojonegoro dan Kantor Urusan Agama Kecamatan di Kabupaten Bojonegoro telah memiliki beberapa program bimbingan yang dilaksanakan dalam memberikan pemahaman berumah tangga supaya tidak mudah untuk memutuskan hubungan rumah tangga dengan sebuah perceraian. Bimbingan merupakan proses pemberian bantuan kepada individu atau kelompok supaya dapat mengatasi kesulitan-kesulitan yang dihadapinya, sehingga selalu berjalan dengan baik dan tidak kehilangan arah. Peranan Kementerian Agama Bojonegoro dalam mengurangi angka perceraian di Kabupaten Bojonegoro adalah sebagai berikut : (Asngari, S.Ag., MA, 2019)

\section{Bimbingan Perkawinan (BINWIN)}

Melalui Keputusan Direktur Jenderal Bimbingan Masyarakat (BIMAS) Islam Nomor 373 Tahun 2017 tentang Petunjuk Teknis Bimbingan Perkawinan Bagi Calon Pengantin, diisntruksikan bahwa setiap laki-laki dan perempuan yang akan melangsungkan perkawinan harus mengikuti bimbingan perkawinan yang diselenggarakan oleh Kementerian Agama, dalam hal ini program BINWIN di Kabupaten Bojonegoro diselenggarakan oleh Kantor Kemenag Kab. Bojonegoro. Materi yang disampaikan dalam bimbingan, adalah :

a. Membangun landasan keluarga sakinah Membangun landasan keluarga sakinah (tentram) sangat penting dan harus dipersiapkan dengan baik, seperti memilih pasangan yang baik, menerapkan kehidupan berumah tangga dengan dasar kasih sayang, memahami peraturan berumah tangga, saling mengerti antara suami dan istri, saling percaya, saling menghargai, menghindari pertikaian hingga menjalankan kewajibannya sebagai suami maupun istri masing-masing dengan baik.

b. Merencanakan perkawinan yang kokoh menuju keluarga sakinah

Hal ini dikarenakan karena pernikahan itu tidak hanya ikatan biasa dan sementara tetapi juga merupakan dasar bagi tumbuh kembangnya masyarakat, karena itu dalam perkawinan memiliki dasar yang kokoh, sehingga pernikahan sampai pada tujuan utamanya yaitu keluarga yang sakinah, mawaddah dan rahmah.

c. Mengelola dinamika perkawinan dan keluarga

Dalam berumah tangga membutuhkan yang namanya kemampuan menjalankan rumah tangga yang baik, karena menjalankan bahtera rumah tangga memiliki sifat yang dinamis, sehingga dibutuhkan pengelolaan dan pembinaan yang baik dalam menghadapi segala persoalan rumah tangga.

d. Memenuhi kebutuhan keluarga

Kebutuhan lahir maupun bathin merupakan dua unsur yang harus dipenuhi dengan baik dalam kehidupan berumah tangga. Kedua hal tersebut harus seimbang dan masing-masing pasangan harus memahami tanggungjawab maupun kewajiban masing-masing kaitannya dengan kebutuhan dalam keluarga.

e. Menjaga kesehatan reproduksi keluarga Menjaga kesehatan reproduksi adalah penting karena kesehatan reproduksi merupakan segala sesuatu yang menyangkut kesehatan seksual dan pendidikan seksual yang bertujuan untuk mencegah, menjaga, dan mengembalikan fungsi organ seksual dari gangguan.

f. Menyiapkan generasi yang berkualitas Keluarga merupakan unit masyarakat terkecil dan memiliki peran yang sangat penting dalam melahirkan generasi berkualitas sebuah bangsa. Sehingga dalam berumah tangga suami-isteri harus memahami dan berupaya 
menyiapkan anak-anak yang berkualitas baik dalam merawat maupun mendidiknya.

g. Mengelola konflik dan membangun ketahanan keluarga

Perselisihan maupun konflik dalam rumah tangga memang akan selalu ada, karena untuk menjadikan rumah tangga yang berwarna butuh yang namanya masalah guna menyempurnakan dan mendewasakan fikiran berumah tangga. Sehingga harus ada pemahaman dan persiapan baik dari pihak suami maupun pihak istri tentang bagaimana mengelola dan mengatur setiap konflik dalam berumah tangga yang baik.

h. Ketahanan keluarga dalam menghadapi tantangan perkawinan

Memberikan bekal materi dalam menghadapi tantangan persoalan dalam perkawinan merupakan hal yang sama pentingnya dengan materi yang lain dalam bimbingan perkawinan. Materi ini sangat penting karena pada hakikatnya calon pengantin rata-rata sebelumnya belum pernah menjalankan rumah tangga yang secara otomatis belum memahami konflik-konflik dan sikap seperti apa yang harus diterapkan untuk menghadapinya.

i. Mengenali dan menggunakan hukum untuk melindungi perkawinan dan keluarga

Memberikan pemahaman tentang hukum sebagai wujud untuk melindungi setiap hak baik suami maupun istri, sehingga hal ini cukup penting bagi setiap pasangan suami istri supaya mengetahui setiap hak-haknya tersebut dan akan menggunakan setiap haknya tersebut dengan baik dan akan berpengaruh terhadap rumah tangga/keluarga.

j. Prosedur pendaftaran dan pencatatan peristiwa nikah atau rujuk

Memberikan pemahaman sebagaimana yang telah dituangkan dalam UU Perkawinan bahwa setiap perkawinan selain dilaksanakan menurut agama dan kepercayaannya masing-masing, maka setiap perkawinan tersebut harus dicatatkan, termasuk peristiwa hukum dalam perkawinan yang lainnya baik terkait pendaftaran nikah maupun rujuk. Sehingga dengan disampaikannya materi tersebut setiap pasangan suamiistri akan memahami tentang kepastian hukum yang didapatkan setelah melakukan setiap perkawinan.

Beberapa cara tersebut secara mayoritas dan keseluruhan masih diselenggarakan oleh Kementerian Agama Kab. Bojonegoro setiap tahunnya, mengingat dalam setiap pelaksanaan bimbingan perkawinan tersebut harus mensyaratkan peserta berjumlah 50 orang atau 25 pasang calon pengantin dalam 1 (satu) kelas bimbingan perkawinan. Sehingga dengan pengaturan seperti itu dimungkinkan cukup sulit dilaksanakan (untuk menyelenggarakan bimbingan perkawinan) oleh Kantor Urusan Agama (KUA) setempat karena sedikitnya jumlah catin yang hendak menikah setiap bulannya, sehingga harus menyetor Catin untuk mengikuti bimbingan ke Kantor Kementerian Agama Kab. Bojonegoro atau bahkan menyelenggarakan bimbingan kawin gabungan dengan KUA yang lain dengan fasilitator dari Kementerian Agama Kab. Bojonegoro.

Asngari, S.Ag., MA menambahkan bahwa guna menghubungkan antara narasumber dengan calon pengantin (peserta), dalam hal ini Kemenag Bojonegoro memfasilitasi dengan baik kaitannya dengan sarana maupun prasarana kegiatan bimbingan perkawinan tersebut, di antaranya adalah sebagai berikut:

a. Sarana pembelajaran berupa bahan ajar atau modul dari Kementerian Agama Kab. Bojonegoro

b. Pembiayaan pelaksanaan bimbingan perkawinan untuk para calon pengantin yang bersumber dari APBN, dana DIPA Kemenag dan PNBP-NR. 
c. Tempat pelaksanaan bimbingan perkawinan (Aula Kemenag Kab. Bojonegoro).

d. Penyediaan alat tulis.

Pelaksanaan bimbingan perkawinan ini setiap peserta (calon pengantin) sama sekali tidak dipungut biaya. Dana pelaksaan bimbingan perkawinan ini berasal dari subsidi silang Pendapatan Negara Bukan Pajak biaya Nikah dan Rujuk (PNBP-NR). Jadi biaya pelaksanaan bimbingan perkawinan ini bersumber dari dana DIPA Kemenag RI dan biaya nikah calon pengantin yang dilaksanakan di luar Kantor Urusan Agama (KUA) sebesar Rp. 600.000,- (enam ratus ribu rupiah) yang secara sebagian disalurkan untuk pelaksanaan bimbingan perkawinan tersebut. Sumber dana pelaksanaan bimbingan perkawinan sesuai dengan $\mathrm{BAB}$ IV huruf (A) Keputusan Direktur Jendral Bimbingan Masyarakat (BIMAS) Islam Nomor 373 Tahun 2017 tentang Petujuk Teknis Bimbingan Perkawinan bagi Calon Pengantin, bahwa Biaya Bimbingan adalah sebagai berikut :

1. Biaya bersumber dari APBN dan/atau PNBP NR.

2. Alokasi biaya Bimbingan Perkawinan Calon Pengantin tercantum dalam daftar isian pelaksanaan anggaran (DIPA) NR Kantor Kementerian Agama Kabupaten/Kota.

3. Biaya Bimbingan Tatap Muka sebesar Rp. 400.000,- (empat ratus ribu rupiah) per pasang atau Rp. 200.000,- (dua ratus ribu rupiah) per orang.

4. Biaya bimbingan mandiri perpasang sebesar Rp. 50.000,- (lima puluh ribu rupiah).

$\begin{array}{ccr}\text { Secara } & \text { teknis } & \text { pelaksanaan } \\ \text { bimbingan } & \text { perkawinan } & \text { yang }\end{array}$ diselenggarakan oleh Kementerian Agama Kabupaten Bojonegoro adalah selama 2 hari yang dilaksanakan pada hari efektif (kerja) dengan masing-masing pelaksanaan dalam 1 (satu) harinya selama 8 (delapan) jam disertai dengan pre test mupun post test, sehingga total ada 16 jam dalam pelaksanaan bimbingan perkawinan dan mewajibkan calon pengantin mengikuti persyaratan yang telah ditentukan oleh KUA yaitu mendaftar, mengisi formulir dan melengkapi administrasi pelaksanaan pernikahan. Dalam pelaksanaan program bimbingan perkawinan ini memang sudah dilaksanakan dengan optimal setiap tahunnya oleh Kemenag Kab. Bojonegoro namun dalam setiap pelaksanaannya tersebut tidak luput dari berbagai kendala maupun hambatan di antaranya adalah sebagai berikut : (Asngari, S.Ag., MA, 2019)

1. Keterbatasan dana

Dalam pelaksanaan program bimbingan perkawinan bagi calon pengantin sangat membutuhkan narasumber yang ahli maupun berkompeten di bidangnya, termasuk memberikan insentif maupun memberikan konsumsi kepada para calon pengantin sebagai peserta, sehingga dana yang dibutuhkan relatif besar sedangkan dana yang digunakan sebagian berasal dari biaya calon pengantin yang menikah di luar Kantor Urusan Agama (KUA). Sedangkan yang mengikuti bimbingan perkawinan adalah semua calon pengantin, baik yang hendak menikah di Kantor Urusan Agama (gratis) maupun yang melaksanakan perkawinan di luar Kantor Urusan Agama dengan biaya sebesar Rp. 600.000,- (Enam ratus ribu rupiah). Sedangkan dana DIPA Kemenag untuk kegiatan BINWIN ini seringkali terlambat dan turunnya tidak tentu waktunya.

2. Minimnya partisipasi dari calon pengantin

Seringkali calon pengantin yang telah diberikan undangan bimbingan perkawinan tidak mengikutinya dengan alasan kurang memiliki kesadaran akan pentingnya bimbingan perkawinan dalam rumah tangga. Terlebih lagi untuk calon pengantin yang sudah pernah menjalankan rumah tangga atau yang sudah berstatus duda maupun janda dan 
mereka cenderung memiliki anggapan bahwa perkawinan itu sama saja dengan atau tanpa bimbingan perkawinan, sehingga mereka tidak membutuhkan bimbingan perkawinan.

3. Kesibukan calon pengantin

Dengan penyelenggaraan bimbingan perkawinan pada hari kerja (efektif) tentu banyak berbenturan dengan kesibukan dari masing-masing calon pengantin yang memiliki pekerjaan dan tidak mendapatkan ijin pada saat kegiatan BINWIN dan rata-rata hanya mendapatkan ijin pada saat akad nikah, sehingga banyak yang berhalangan karena tidak mendapatkan ijin atau bahkan ada pula yang hanya salah satu pasangan saja yang mengikuti hingga banyak juga yang hanya mengikuti beberapa jam saja dalam materi bimbingan perkawinan tersebut.

\section{Bimbingan Pra-Nikah Non Calon Pengantin (Non-Catin)}

$\begin{array}{cc}\text { Selain } & \text { program } \\ \text { perkawinan } & \text { bimbingan } \\ \text { (BINWIN) yang telah }\end{array}$ diuraikan di atas bahwa Kementerian Agama Kabupaten Bojonegoro juga memiliki program/kegiatan lain yang diharapkan mampu memberikan pemahaman berumah tangga dan khusunya dapat meminimalisir perceraian di Kabupaten Bojonegoro. Program tersebut adalah bimbingan pra-nikah non calon pengantin (Non-Catin) dan yang menjadi target program bimbingan ini adalah setiap anak usia nikah tapi belum ingin melangsungkan perkawinan. Sesuai dengan UU Perkawinan bahwa batas usia perkawinan anak untuk laki-laki adalah 19 tahun dan untuk perempuan adalah 16 tahun. Usia nikah menurut Asngari, S.Ag., MA selaku Staff Seksi Bimas Islam Kab. Bojonegoro adalah anak yang telah berusia antara 16-21 tahun, di mana yang menjadi sasaran adalah anak-anak di tingkat SMA/SMK/MA maupun mahasiswa pada Perguruan Tinggi yang berada di Kabupaten Bojonegoro.
Pada tahun 2018 kurang lebih Kementerian Agama Bojonegoro juga telah melaksanakan bimbingan pra-nikah non catin ini di beberapa lembaga pendidikan di antaranya adalah : (Asngari, S.Ag., MA, 2019)

1. Institute Agama Islam (IAI) Sunan Giri Kab. Bojonegoro

2. Sekolah Tinggi Agama Islam (STAI) At Tanwir Kabupaten Bojonegoro

Tujuan daripada penyelenggaraan bimbingan pra-nikah non-catin dilandasi dengan banyaknya problem perceraian dan tidak matangnya persiapan berumah tangga yang dikarenakan usia muda memang usia yang bergejolak dan riskan dengan hal-hal yang negatif, sehingga program bimbingan pra-nikah non catin yang dilaksanakan oleh Kementerian Agama Kabupaten Bojonegoro bertujuan sebagai berikut :

1. Membentuk karakter remaja agar mampu mandiri saat sudah memutuskan untuk berumah tangga.

2. Pembekalan kepada para remaja sebelum mengarungi kehidupan berumah tangga yang baik.

3. Mempersiapkan rumah tangga yang yang diinginkan yaitu sakinah, mawaddah dan rahmah.

4. Mengantisipasi permasalahan yang kurang baik seperti gagalnya membentuk keluarga bahagia dan sejahtera.

5. Memberikan pengertian dan pemahaman yang baik tentang essestensi pernikahan untuk membentuk keluarga bahagia dan sejahtera, memberikan solusi alternatif dari kondisi yang rapuh dan rentannya rumah tangga yang berujung perceraian.

6. Merencanakan keluarga yang baik dan berkualitas.

Asngari, S.Ag., MA menambahkan bahwa berkaitan dengan materi sosialisasi bimbingan perkawinan non-catin yang diselenggarakan oleh Kemenag Kab. Bojonegoro pada intinya hampir sama dengan materi-materi pada program Bimbingan Perkawinan (BINWIN), akan 
tetapi karena waktu penyampaian bimbingan pra-nikah ini sangat terbatas hanya sekitar 1-2 jam dan dirangkai dalam bentuk sosialisasi. Namun materi-materi yang disampaikan juga tidak jauh berbeda dengan materi BINWIN, di antaranya adalah sebagai berikut :

1. Mempersiapkan kesiapan diri untuk menikah;

2. Mematangkan dan memutuskan usia untuk menikah;

3. Memberikan gambaran berumah tangga;

4. Memberikan pandangan dalam menjalani rumah tangga;

5. Memberikan solusi jika muncul permasalahan dalam rumah tangga;

6. Memberikan gambaran membentuk rumah tangga yang bahagia, sakinah, mawaddah dan rahmah.

Secara teknis pelaksanaan

bimbingan pra-nikah non catin ini oleh Kementerian Agama Bojonegoro melalui Seksi BIMAS Islam berinisiatif dengan melakukan koordinasi melalui surat yang ditujukan kepada instansi atau lembaga pendidikan yang bersedia bekerjasama melangsungkan program bimbingan pranikah tersebut. Sehingga setelah disetujuinya surat oleh lembaga pendidikan tersebut, maka Kementerian Agama Kab. Bojonegoro menindaklanjuti dengan mempersiapkan pemateri dalam bimbingan, konsumsi, hingga alat tulis yang menunjang pelaksanaan, sedangkan pihak lembaga pendidikan yang telah menyetujui tersebut menyediakan tempat dan jumlah bahkan pihak lembaga pendidikan juga dapat berkolaborasi dalam memberikan materi bimbingan terhadap para peserta dalam sosialisasi bimbingan pra-nikah non catin tersebut. Selama ini program bimbingan pra-nikah bagi non calon pengantin mendapatkan antusias yang luar biasa dari lembaga pendidikan dan khususnya remaja yang mendapatkan bimbingan. Hal tersebut terjadi karena mereka memiliki kesadaran dan menganggap bimbingan maupun bekal yang disampaikan dalam sosialisasi adalah penting untuk mengarungi dan menjalankan bahtera kehidupan rumah tangga menuju keluarga yang sakinah, mawaddah dan rahmah (Asngari, S.Ag., MA, 2019).

Selain beberapa program yang sifatnya preventif dari Kementerian Agama Kabupaten Bojonegoro, bahwa dari ke-28 Kantor Urusan Agama (KUA) seKabupaten Bojonegoro yang merupakan wilayah administratif/yang melaksanakan sebagian tugas kantor Kementerian Agama Indonesia di Kabupaten dan Kotamadya di bidang urusan agama Islam dalam wilayah Kecamatan. Kantor Urusan Agama (KUA) pada dasarnya juga memiliki beberapa program yang sifatnya mencegah berupa rangkaian pembekalan pra-nikah bagi calon pengantin maupun yang sifatnya pembinaan pada setiap keluarga yang menjalankan kehidupan berumah tangga. Beberapa program tersebut berhasil peneliti kumpulkan dari masing-masing Kantor Urusan Agama (KUA) yang ada di Kabupaten Bojonegoro, di antaranya adalah sebagai berikut :

\section{Bimbingan Perkawinan (BINWIN)}

Menurut Kepala dan beberapa Penghulu dari ke-28 (Dua Puluh Delapan) Kantor Urusan Agama (KUA) di Kabupaten Bojonegoro, rata-rata berpendapat bahwa bimbingan perkawinan (Binwin) bagi calon pengantin merupakan penyempurnaan program terbaru atas Kursus Calon Pengantin (Suscatin) oleh Kementerian Agama Republik Indonesia sebagai bentuk keprihatinan atas tingginya perceraian supaya dijadikan sebagai landasan membimbing dan membekali setiap pasangan calon pengantin yang akan menikah supaya memiliki dasar dan pondasi yang tangguh dan kokoh dalam mengarungi kehidupan berumah tangga. Bimbingan perkawinan ini masih dilaksanakan secara sektoral oleh kantor Kementerian Agama Kabupaten Bojonegoro yang dianggap sebagai salah satu program atau upaya pembekalan paling sempurna karena mulai dari pemateri/tutor, 
materi/modul pembelajaran, konsep jadwal dipersiapkan secara keseluruhan oleh Kantor Kemenag Kabupaten Bojonegoro. Ketentuan Binwin sebagaimana telah diuraikan oleh Seksi BIMAS Islam di atas bahwa Binwin dilaksanakan selama 2 (dua) hari kerja dengan jadwal setiap harinya selama 8 (delapan) jam, dan diikuti oleh minimal 25 pasangan (50 orang) setiap kelasnya. Namun sejauh ini hampir sebagian besar kegiatan Binwin belum berjalan secara efektif di wilayah KUA Kecamatan dikarenakan jumlah angka perkawinan yang berbeda di setiap wilayah KUA dan hanya berjalan cukup baik di KUA yang memiliki wilayah luas seperti wilayah KUA Kec. Sumberrejo, Kec. Baureno dan KUA Kec. Kanor, selain itu dikarenakan juga akan ketidakpastian waktu mengenai kapan pelaksanaan Binwin karena sangat bergantung pada anggaran negara yang pencairannya sangat tidak menentu, sehingga tidak setiap waktu calon pengantin yang akan menikah bisa mendapatkan bimbingan perkawinan. Di dalam Binwin dilengkapi dengan beragam fasilitas bagus seperti pemateri yang bersertifikat, modul materi, konsumsi, outbond, pre-test post-test, sehingga akan sangat berkesan dan bagus untuk memperkokoh dasar kehidupan rumah tangga. Materi dalam Binwin di antaranya seperti :

a. Menjaga keutuhan rumah tangga;

b. Mempersiapkan mental yang tangguh dalam keluarga;

c. Mempersiapkan keturunan yang baik dan berkualitas;

d. Mengolah setiap konflik dengan baik dalam rumah tangga;

e. Menguraikan dinamika yang terjadi dalam rumah tangga;

f. Memenuhi kebutuhan lahir bathin dalam rumah tangga;

g. Mendasarkan hukum untuk melindungi hubungan perkawinan.

Penyampaian materi-materi Binwin tersebut dipersiapkan dalam sebuah jadwal pelaksanaan yang telah disusun oleh panitia, sebagai berikut :

\begin{tabular}{|c|c|c|}
\hline HARI & WAKTU & MATERI \\
\hline \multirow{6}{*}{$\begin{array}{c}1 \\
\text { (PERT } \\
\text { AMA) }\end{array}$} & $\begin{array}{c}08.00-08.30 \\
\text { WIB }\end{array}$ & $\begin{array}{l}\text { PRE-TEST DAN } \\
\text { PEMBUKAAN }\end{array}$ \\
\hline & $\begin{array}{c}08.30-10.00 \\
\text { WIB }\end{array}$ & $\begin{array}{l}\text { PERKENALAN } \\
\text { DAN KONTRAK } \\
\text { BELAJAR }\end{array}$ \\
\hline & $\begin{array}{c}10.00-12.00 \\
\text { WIB }\end{array}$ & $\begin{array}{l}\text { MENGELOLA } \\
\text { DINAMIKA } \\
\text { PERKAWINAN } \\
\text { DAN } \\
\text { KELUARGA }\end{array}$ \\
\hline & $\begin{array}{c}12.00-13.00 \\
\text { WIB }\end{array}$ & $\begin{array}{l}\text { ISTIRAHAT, } \\
\text { MAKAN SIANG } \\
\text { DAN SHOLAT } \\
\text { DHUHUR }\end{array}$ \\
\hline & $\begin{array}{c}13.00-15.00 \\
\text { WIB }\end{array}$ & $\begin{array}{l}\text { MEMPERSIAPK } \\
\text { AN } \\
\text { PERKAWINAN } \\
\text { YANG KOKOH } \\
\text { MENUJU } \\
\text { KELUARGA } \\
\text { SAKINAH }\end{array}$ \\
\hline & $\begin{array}{c}15.00-17.00 \\
\text { WIB }\end{array}$ & $\begin{array}{l}\text { MEMENUHI } \\
\text { KEBUTUHAN } \\
\text { KELUARGA }\end{array}$ \\
\hline \multirow{6}{*}{$\begin{array}{c}2 \\
(\mathrm{KEDU} \\
\mathrm{A})\end{array}$} & $\begin{array}{c}08.00-10.00 \\
\text { WIB }\end{array}$ & $\begin{array}{l}\text { MENJAGA } \\
\text { KESEHATAN } \\
\text { REPRODUKSI } \\
\text { KELUARGA } \\
\end{array}$ \\
\hline & $\begin{array}{c}10.00-12.00 \\
\text { WIB }\end{array}$ & $\begin{array}{l}\text { MEMPERSIAPK } \\
\text { AN GENERASI } \\
\text { BERKUALITAS }\end{array}$ \\
\hline & $\begin{array}{c}12.00-13.00 \\
\text { WIB }\end{array}$ & $\begin{array}{l}\text { ISTIRAHAT, } \\
\text { MAKAN SIANG } \\
\text { DAN SHOLAT } \\
\text { DHUHUR }\end{array}$ \\
\hline & $\begin{array}{c}13.00-15.00 \\
\text { WIB }\end{array}$ & $\begin{array}{l}\text { MENGELOLA } \\
\text { KONFLIK DAN } \\
\text { MEMBANGUN } \\
\text { KETAHANAN } \\
\text { KELUARGA }\end{array}$ \\
\hline & $\begin{array}{c}15.00-16.30 \\
\text { WIB }\end{array}$ & $\begin{array}{l}\text { REFLEKSI DAN } \\
\text { EVALUASI }\end{array}$ \\
\hline & $\begin{array}{c}16.30-17.00 \\
\text { WIB }\end{array}$ & $\begin{array}{l}\text { POST-TEST DAN } \\
\text { PENUTUPAN }\end{array}$ \\
\hline
\end{tabular}




\section{Penasehatan Pra-Nikah}

Penasehatan pra-nikah pada dasarnya merupakan serangkaian kegiatan bimbingan yang masuk pada proses pemeriksaan perkawinan sebagaimana ketentuan Pasal 5 ayat 1 Peraturan Menteri Agama Nomor 19 Tahun 2018 tentang Pencatatan Perkawinan bahwa Kepala KUA Kecamatan atau Penghulu melakukan pemeriksaan dokumen perkawinan. Di dalam rangkaian pemeriksaan perkawinan tersebut KUA menyisipkan proses penasehatan kepada calon pengantin sebagai upaya pembekalan agar memiliki pedoman berumah tangga yang tangguh. Sejalan dengan pemeriksaan dokumen perkawinan tersebut seluruh KUA Kecamatan yang ada di Kabupaten Bojonegoro memberlakukan secara wajib kepada calon pengantin untuk mendapatkan pemahaman dan penasehatan pra-nikah dengan durasi waktu rata-rata selama \pm 30 menit secara face to face (tatap muka) kepada setiap pasangan calon pengantin di ruangan yang telah disediakan oleh KUA dan dilakukan dengan metode ceramah oleh penyuluh fungsional, Penghulu maupun oleh Kepala KUA, dengan materi-materi penasehatan yang hampir mirip pada kegiatan bimbingan perkawinan (Binwin), yaitu sebagai berikut :

a. Memilih jodoh (pasangan hidup) yang baik

Mengingat perkawinan merupakan salah satu bagian terpenting dalam menciptakan keluarga dan masyarakat yang di ridhoi Allah swt maka dalam memilih calon istri atau suami, sehingga dianjurkan agar berdasarkan segala sesuatunya atas norma agama, sehingga pendamping hidup nantinya mempunyai akhlak/norma yang terpuji.

b. Syarat dan Rukun Nikah Perkawinan perkawinan yang penuh dengan nilai dan bertujuan kehidupan rumah tangga yang sakinah, mawadah dan penuh rahmah, perlu diatur dengan syarat dan rukun tertentu.

c. Mahar dan ijab qabul
Maskawin atau mahar dalam Islam adalah hak bagi wanita, disamping itu mahar juga merupakan penghormatan hak-hak wanita, khususnya dalam masalah harta, namun mahar tidak ada ketentuan besar dan banyaknya yang pasti, tetapi diserahkan pada kerelaan masing-masing. Sedangkan ijab qabul merupakan prosesi yang dilangsungkan antara calon mempelai laki-laki dan wali dari mempelai wanita yang disaksikan oleh dua orang saksi.

d. Menyiapkan generasi (reproduksi) yang berkualitas

Mendapatkan sebuah keturunan adalah harapan/dambaan sebuah keluarga, namun mempersiapkan generasi yang bagus dan berkualitas patut dipersiapkan oleh sebuah keluarga dengan baik.

e. Mengelola konflik dan membangun ketahanan keluarga

Setiap masalah rumah tangga apabila tidak dikelola dan dihadapi dengan baik, sudah pasti jalan darurat menuju perceraian semakin terbuka lebar. Namun jika sebuah keluarga telah mempersiapkan kedewasaan dalam menghadapi permasalahan dengan baik, maka semua permasalahan akan menjadikan rumah tangga semakin kuat.

f. Persiapan Perkawinan

Dalam persiapan perkawinan KUA Malo menghimbau supaya calon pengantin memperhatikan 4 (empat) aspek yaitu :

1. Aspek biologis;

2. Aspek mental pshikologi;

3. Aspek spiritual;

4. Aspek psikososial.

Selain 4 aspek tersebut calon pengantin juga harus mempersiapkan: kesiapan batin/rohani, memeriksakan kesehatan dan mengikuti kursus calon pengantin (Bimbingan Perkawinan).

g. Perilaku yang harus dimiliki oleh suami isteri

Demi menjaga hubungan rumah tangga yang harmonis tentu harus berpegang tegug pada sikap-sikap baik yang 
dimiliki oleh pasangan suami isteri, yaitu :

1. Saling menasehati/mengingatkan dalam mengamalkan syariatagama islam;

2. Saling mencintai dan menyayangi;

3. Saling musyawarah, terbuka dan jujur;

4. Saling menyimpan rahasia rumah tangga dan aib/pribadi;

5. Saling menyadari tugas masingmasing dalam rumah tangga dengan penuh amanah.

h. Perilaku yang harus dihindari oleh suami isteri

Selain sifat baik yang harus ditanamkan dalam keluarg juga terdapat sifak atau perilaku buruk yang harus dihindari, yaitu :

1. Memerintah dengan semena-mena;

2. Mudah menerima aduan orang lain;

3. Meninggalkan rumah tanpa sepengetahuan suami atau isteri;

4. Mudah marah dan cemburu buta;

5. Melakukan perbuatan maksiat dan bergaul bebas tanpa terkendali;

6. Mempermudah ucapan talaq/cerai kepada isteri;

\section{Penyuluhan Keluarga Sakinah}

Keluarga Sakinah adalah keluarga yang telah dapat memenuhi seluruh kebutuhan keimanan, ketaqwaan dan akhlakul karimah secara sempurna, kebutuhan sosial psikologis, dan pengembangannya serta dapat menjadi suri teladan bagi lingkungannya. Suami atau istri adalah rekan dalam mengambil keputusan, oleh karena itu keduanya harus menjaga emosi yang berlebihan, berhatihati dengan kata-kata yang digunakan, dan senantiasa menunjukkan kasih sayang (Asngari, S.Ag., MA, 2019. Pada bidang seksi Bimbingan Masyarakat (BIMAS) Islam Kantor Kementerian Agama Kab. Bojonegoro memiliki Penyuluh PNS di tiap-tiap kantor KUA (ada yang merangkap 2 tempat KUA) sebagai koordinator terhadap 8 penyuluh agama islam non-PNS yang ada di setiap kantor KUA masing- masing dengan jumlah 8 (delapan) bidang formasi tersebut di antaranya adalah :

1. Keluarga Sakinah;

2. Pemberantasan Narkoba;

3. Pemberantasan Buta Huruf Al-Qur'an;

4. Produk Halal;

5. Kerukunan Umat Beragama;

6. Pemberantasan Aliran Radikalisme;

7. Zakat;

8. Wakaf.

Dalam hal ini kaitannya dengan peranan KUA untuk mengurangi angka perceraian di masyarakat, maka KUA SeKabupaten Bojonegoro telah mengoptimalkan keberadaan penyuluh non PNS bidang Keluarga Sakinah untuk melakukan penyuluhan dan pembinaan terhadap setiap masyarakat di seluruh desa yang ada pada 28 (dua puluh delapan) Kecamatan di Kabupaten Bojonegoro. Target/sasaran binaan atau kegiatan penyuluhan keluarga sakinah adalah :

a. Perkumpulan Majelis Ta'lim;

b. Perkumpulan Majelis Tahlil;

c. Perkumpulan PKK Desa;

d. Guru-guru Madrasah Diniyah dan TPQ.

Berikut ini merupakan dasar acuan penyuluhan yang dilakukan oleh petugas penyuluh kepada masyarakat sebagai upaya membentuk rumah tangga yang sakinah, mawaddah dan rahmah, sesuai dengan Keputuan Direktur Jenderal Bimbingan Masyarakat Islam dan Urusan Haji nomor: D/71/1999 tentang Petunjuk Pelaksanaan Pembinaan Gerakan Keluarga Sakinah Bab III Pasal 3, terdapat klasifikasi tentang Keluarga Sakinah yaitu :

1. Keluarga Sakinah I

a. Keluarga tersebut dibentuk melalui perkawinan yang sah berdasarkan peraturan yang berlaku atas dasar cinta kasih dan kasih sayang;

b. Melaksanakan Sholat;

c. Melaksanakan Puasa;

d. Membayar Zakat Fitrah;

e. Mempelajari dasar agama;

f. Mampu membaca Al-Quran;

g. Memiliki pendidikan dasar;

h. Ada tempat tinggal; 
i. Memiliki pakaian.

2. Keluarga Sakinah II

a. Memenuhi kriteria Sakinah I;

b. Hubungan anggota keluarga harmonis;

c. Keluarga menamatkan sekolah 9 Tahun;

d. Mampu berinfaq;

e. Memiliki tempat tinggal sederhana;

f. Mempunyai tanggungjawab kemasyarakatan;

g. Memenuhi kebutuhan gizi keluarga.

3. Keluarga Sakinah III

a. Memenuhi kriteria Sakinah II;

b. Membiasakan sholat jamaah;

c. Pengurus pengajian/organisasi;

d. Memiliki tempat tinggal layak;

e. Memahami pentingnya kesehatan keluarga;

f. Harmonis;

g. Gemar memberikan shodaqah;

h. Melaksanakan qurban;

i. Keluarga mampu memenuhi tugas dan kewajiban masing-masing;

j. Pendidikan minimal SLTA.

4. Keluarga Sakinah III Plus

a. Memenuhi kriteria Sakinah III;

b. Keluarga tersebut dapat menunaikan ibadah haji;

c. Salah satu keluarga menjadi pimpinan organisasi Islam;

d. Mampu melaksanakan wakaf;

e. Keluarga mampu mengamalkan pengetahuan agama kepada masyarakat;

f. Keluarga menjadi panutan masyarakat;

g. Keluarga dan anggotanya Sarjana minimal di Peguruan Tinggi;

h. Keluarga yang menjunjung tinggi nilai-nilai akhlaqaul karimah;

i. Keluarga yang di dalamnya tumbuh cinta dan kasih sayang.

Beberapa metode penyampaian penyuluhan ini oleh penyuluh keluarga sakinah di antaranya adalah sebagai berikut

a. Metode ceramah
Metode ceramah ini memiliki pengertian dengan maksud untuk menyampaikan keterangan, petunjuk, pengertian dan penjelasan tentang sesuatu kepada pendengar dengan menggunakan lisan. Metode ceramah merupakan suatu teknik penyuluhan yang diwarnai oleh ciri-ciri karakteristik berbicara oleh seorang penyuluh pada suatu sktivitas penyuluhan. Metode ini harus diimbangi dengan kepandaian khusus tentang retorika, diskusi, dan faktor-faktor lain yang membuat pendengar merasa simpatik dengan ceramahnya (Samsul Munir Amin, 2009).

b. Metode tanya jawab

Metode tanya jawab adalah metode yang dilakukan dengan menggunakan tanya jawab untuk mengetahui sejauh mana ingatan atau fikiran seseorang memahami atau menguasai materi dakwah atau penyuluhan (Samsul Munir Amin, 2009). Metode tanya jawab ini digunakan sebagai sebuah cara menyajikan materi penyuluhan harus digunakan secara bersama-sama dengan metode lain seperti ceramah, karena metode tanya jawab ini digunakan yang sifatnya membantu kekurangankekurangan yang terdapat pada metode ceramah.

c. Metode silaturrahmi

Metode silaturrahmi ini merupakan penyuluhan yang dilakukan dengan mengadakan kunjungan kepada suatu objek tertentu dalam rangka menyampaikan isi dakwah kepada penyuluhan. Biasanya metode ini digunakan jika ada masalah yang mesti diselesaikan dan menggunakan pendekatan konseling. Konseling memiliki artian membantu individu untuk mengatasi masalah-masalahnya dan membantu individu mencapai perkembangan diri yang optimal dengan sumber-sumber yang ada pada dirinya sendiri. Dalam konseling ada hubungan membantu, di mana penyuluh memberikan kesempatan kepada 
kliennya untuk menemukan solusi dari masalah yang dihadapi kliennya, untuk mendapatkan solusi dari masalah yang dihadapinya, sehingga kehidupannya bisa lebih baik (Tulus, dkk, 2012)

d. Metode keteladanan

Metode keteladanan sendiri memiliki artian penyajian dakwah atau penyuluhan dnegan memberikan keteladanan langsung kepada masyarakat, sehingga tersuluh akan tertarik ikut kepada apa yang dicontohkan oleh penyuluh. Metode penyuluhan ini dapat digunakan untuk hal-hal yang berkaitan dengan akhlak, cara bergaul, cara beribadah, cara berumah tangga dan aspek lain dalam kehidupan setiap manusia (Samsul Munir Amin, 2009).

Sehingga ketika diperingkas materimateri penyuluhan oleh petugas di seluruh KUA Kecamatan yang ada di Kabupaten Bojonegoro kepada masyarakat dalam membentuk keluarga sakinah sebagaimana kualifikasi di atas, adalah sebagai berikut:

a. Menjaga hubungan yang baik antara suami istri;

b. Menanamkan keadilan dalam kehidupan keluarga;

c. Adanya rasa kasih sayang dan penghormatan kepada setiap anggota keluarga;

d. Menghargai kemampuan masingmasing pasangan;

e. Menjaga dan menyimpan rahasia keluarga;

f. Mendidik anak dengan cara-cara yang baik dan sabar, agar mereka mengenal dan mencintai Allah SWT;

g. Menanamkan rasa syukur dalam keluarga;

h. Menjaga akidah akhlak suami isteri serta anak-anak dalam rumah tangga;

i. Membangun pergaulan sosial yang sehat;

j. Membiasakan kehidupan rumah tangga yang sederhana dan tidak mengikuti modernisasi semata; k. Menjadikan agama sebagai pedoman hidup berumah tangga;

1. Mensikapi persoalan rumah tangga dengan dengan ikhlas;

$\mathrm{m}$. Suami isteri mampu menyeimbangkan karir dan urusan rumah tangga dengan baik;

n. Mudah memaafkan kesalahan setiap pasangan suami maupun isteri.

\section{SIMPULAN}

Bahwa peran dari Kementerian Agama Kabupaten Bojonegoro dan Kantor Urusan Agama (KUA) di Kabupaten Bojonegoro dalam upaya mengurangi angka perceraian di Kabupaten Bojonegoro sudah dioptimalkan dengan beberapa kebijakan di antaranya adalah sebagai berikut :
a. Program Bimbingan Perkawinan (BINWIN);
b. Program Penasehatan Pra-Nikah Non Calon Pengantin (Non Catin);
c. Penasehatan Pra-Nikah bagi Calon Pengantin (Pemeriksaan Perkawinan/Rapak);
d. Penyuluhan Keluarga Sakinah.

\section{SARAN}

Berdasarkan simpulan dari Kementerian Agama dan Kantor Urusan Agama di Kabupaten Bojonegoro, selama ini sudah sangat optimal dalam memberikan pembekalan, penasehatan, pondasi pranikah supaya dalam kehidupan berumah tangga dapat harmonis dan terhindar dari sebuah perceraian. Namun yang menjadi poin penting adalah Pengadilan Agama jangan terlalu mudah memutus sebuah perkara perceraian dan Kementerian Agama dan Kantor Urusan Agama di Kabupaten Bojonegoro berharap mekanisme pengajuan perceraian dapat disinergikan lagi dengan pihak BP4 (Badan Penasihatan Pembinaan dan Pelestarian Perkawinan), sehingga akan muncul sebuah filter bagi para pihak yang akan mengajukan perceraian, karena menganggap saat ini Pengadilan Agama 
terlalu mudah dalam menerima, memeriksa dan memutus perkara perceraian.

\section{DAFTAR PUSTAKA}

\section{Referensi dari Buku:}

Mahmud Marzuki Peter. (2009). Penelitian Hukum. Jakarta. Kencana Prenada Media Group

Syarifuddin Amir. (2009). Hukum Perkawinan Islam di Indonesia "Antara Fiqh Munakahat dan Undang-Undang Perkawinan". Jakarta. Kencana

Ashshofa Burhan. (2010). Metode Penelitian Hukum. Jakarta. Rieneka Cipta

Syaifuddin Muhammad dkk. (2013). Hukum Percerian. Jakarta. Sinar Grafika

Fajar Mukti, Achmad Yulianto. (2017). Dualisme Penelitian Hukum Normatif dan Empiris, Yogyakarta. Pustaka Pelajar

\section{Referensi dari Wawancara:}

1. Wawancara dengan Bapak Asngari, S.Ag., MA selaku Staff Seksi Bimas Kementerian Agama Kabupaten Bojonegoro

2. Wawancara dengan Bapak Drs. H. Maulan, M.Ag selaku Kepala Kantor Urusan Agama (KUA) Kecamatan Kepohbaru Kabupaten Bojonegoro.

3. Wawancara dengan Bapak Drs. H. Makhful, M.Ag selaku Kepala Kantor Urusan Agama (KUA) Kecamatan Baureno Kabupaten Bojonegoro

4. Wawancara dengan Bapak Mochammad Charis selaku Kepala Kantor Urusan Agama (KUA) Kecamatan Bojonegoro Kabupaten Bojonegoro

5. Wawancara dengan Bapak Drs. Jauhar Shodri selaku Kepala Kantor Urusan Agama (KUA) Kecamatan Kapas Kabupaten Bojonegoro

6. Wawancara dengan Bapak Drs. H. Mohammad Hasan Bisyri selaku Kepala Kantor Urusan Agama (KUA) Kecamatan Balen Kabupaten Bojonegoro
7. Wawancara dengan Bapak $H$. Masbukhin Elya, S.Ag., M.Hi selaku Kepala Kantor Urusan Agama (KUA) Kecamatan Sumberrejo Kabupaten Bojonegoro

8. Wawancara dengan Bapak Drs. H. M. Nurul Huda, M.Hi selaku Kepala Kantor Urusan Agama (KUA) Kecamatan Trucuk Kabupaten Bojonegoro

9. Wawancara dengan Bapak H. Mahfuri, S.Ag., M.Pd.I selaku Kepala Kantor Urusan Agama (KUA) Kecamatan Sukosewu Kabupaten Bojonegoro

10. Wawancara dengan Bapak Drs. Syamsuddin, M.Hi selaku Kepala Kantor Urusan Agama (KUA) Kecamatan Kanor Kabupaten Bojonegoro

11. Wawancara dengan Bapak Drs. Tadjuddin, SH selaku Kepala Kantor Urusan Agama (KUA) Kecamatan Dander Kabupaten Bojonegoro

12. Wawancara dengan Bapak Warsito, S.Ag selaku Kepala Kantor Urusan Agama (KUA) Kecamatan Bubulan Kabupaten Bojonegoro

13. Wawancara dengan Bapak Warsito, S.Ag selaku Plt Kepala Kantor Urusan Agama (KUA) Kecamatan Sekar Kabupaten Bojonegoro

14. Wawancara dengan Bapak Sahudi, S.HI selaku Kepala Kantor Urusan Agama (KUA) Kecamatan Malo Kabupaten Bojonegoro

15. Wawancara dengan Bapak Arisyon, S.HI selaku Kepala Kantor Urusan Agama (KUA) Kecamatan Ngasem Kabupaten Bojonegoro

16. Wawancara dengan Bapak Ahmad Maqin, S.Fil.I selaku Kepala Kantor Urusan Agama (KUA) Kecamatan Ngambon Kabupaten Bojonegoro

17. Wawancara dengan Bapak Drs. Agus Zali, M.HI selaku Kepala Kantor Urusan Agama (KUA) Kecamatan Purwosari Kabupaten Bojonegoro

18. Wawancara dengan Bapak Drs. Agus Zali, M.HI selaku Plt Kepala Kantor 
Urusan Agama (KUA) Kecamatan Gayam Kabupaten Bojonegoro

19. Wawancara dengan Bapak M. Miran QR, S.Ag., M.HI selaku Kepala Kantor Urusan Agama (KUA) Kecamatan Kasiman Kabupaten Bojonegoro

20. Wawancara dengan Bapak M. Miran QR, S.Ag., M.HI selaku Plt Kepala Kantor Urusan Agama (KUA) Kecamatan Kedewan Kabupaten Bojonegoro

21. Wawancara dengan Bapak Ach. Yulkhaidir, M.Pd.I selaku Kepala Kantor Urusan Agama (KUA) Kecamatan Tambakrejo Kabupaten Bojonegoro

22. Wawancara dengan Bapak Hamim Thohari S, S.Hum selaku Kepala Kantor Urusan Agama (KUA) Kecamatan Padangan Kabupaten Bojonegoro

23. Wawancara dengan Bapak H. Mujib, S.Ag., MM selaku Kepala Kantor Urusan Agama (KUA) Kecamatan Ngraho Kabupaten Bojonegoro
24. Wawancara dengan Bapak Drs. H. Mokh. Kholiq, M.Pd.I selaku Kepala Kantor Urusan Agama (KUA) Kecamatan Margomulyo Kabupaten Bojonegoro

25. Wawancara dengan Bapak Abdul Wahid, S.Ag selaku Pejabat Penghulu Kantor Urusan Agama (KUA) Kecamatan Temayang Kabupaten Bojonegoro

26. Wawancara dengan Bapak Margono, S.Pd.I selaku Kepala Kantor Urusan Agama (KUA) Kecamatan Gondang Kabupaten Bojonegoro

27. Wawancara dengan Bapak Jumari, S.IP selaku Pejabat Penghulu Kantor Urusan Agama (KUA) Kecamatan Sugihwaras Kabupaten Bojonegoro

28. Wawancara dengan Bapak Drs. Sutaji, M.HI selaku Pejabat Penghulu Kantor Urusan Agama (KUA) Kecamatan Kedungadem Kabupaten Bojonegoro

29. Wawancara dengan Bapak Drs. Ali Imron, M.HI selaku Kepala Kantor Urusan Agama (KUA) Kecamatan Kalitidu Kabupaten Bojonegoro. 